\title{
Antenatal ultrasonography in Cameroon (Central Africa): a review of the past 30 years
}

\begin{abstract}
Background: In Cameroon like other SubSaharan African countries, advances in antenatal ultrasonography (AU) have not been used to improve maternal and child health.

Objective: To review the past 30 years of practice of AU in Cameroon.

Methods: A narrative litterature review covering the period ranging from January 1st 1990 to May 31st 2018 was perfomed in Google Scholar and Medline (Pubmed). Only studies conducted in Cameroon with AU as primary or secondary theme were included.

Results: 48 articles were analysed. From 1990 to 2012 there were 0.5 article / year and 6 articles / year from 2013 to 2018. Cases reports were predominant (56.2\%) followed by original clinical researches (35.4\%). No experimental study was found. Almost all the studies were carried out in urban settings $(97.9 \%)$. Main themes of those articles were: fetal malformations $(33.3 \%)$, obstetrical emergencies $(20.8 \%)$ extra-uterine pregnancy $(20.8 \%)$. Articles were mainly published in general medicine (37.4\%) and gynaeco-obstetric journals $(31.2 \%)$. The outreach of those journals was predominantly global $(56.3 \%)$ and African $(25.0 \%)$
\end{abstract}

Conclusion: Scientific litterature on $\mathrm{AU}$ in Cameroon is rare and its technologic and methodological impact is weak.

Keywords: obstetric, ultrasound, echography, Cameroon, antenatal
Volume 10 Issue 5 - 2019

Jovanny Tsuala Fouogue,' Ymele Florent Fouelifack, ${ }^{2}$ Bruno Kenfack, ${ }^{3}$ Jean Marie Pellegrinelli, ${ }^{4}$ Jeanne Hortence Fouedjio, ${ }^{5}$ Patrick Petignat, ${ }^{4}$ Zacharie Sando ${ }^{5}$

'Department of Obstetrics and Gynecology of the Bafoussam Regional Hospital, Cameroon

${ }^{2}$ Yaounde Central Hospital, Cameroon

${ }^{3}$ Faculty of Medicine and Pharmaceutical Sciences of the University of Dschang, Cameroon

${ }^{4}$ Department of Obstetrics and Gynecology of the Geneva

University Hospitals, Switzerland

${ }^{5}$ Faculty of Medicine and Biomedical Sciences of the University of Yaounde I, Cameroon

Correspondence: Fouogue Tsuala Jovanny, Department of Obstetrics and Gynecology of the Bafoussam Regional Hospital, PO Box 980, Cameroon, Tel (+237) 694595 377, Email fotsujo@outlook.com

Received: March 09, 2019 | Published: October 17, 2019

\section{Introduction}

Since its debuts in 1940s echography has revolutionized fetal imaging and antenatal care. ${ }^{1,2}$ Indeed, it is unanimously admitted that antenatal ultrasonography (AU) has led to major progress in antenatal care in terms of materno-fetal and neonatal morbi-mortality. ${ }^{3-6} \mathrm{AU}$ is currently the first line imaging technique for antenatal care in highincome countries. ${ }^{1}$ Nowadays ultrasound machines are more compact, performant and portable; this feeds the rising trend of bedside and consultation room echography. ${ }^{2}$

Nevertheless, in low-income countries and particularly in SubSaharan Africa, health systems have not been able to popularized AU to benefit from it numerous advantages in materno-foetal and neonatal care. ${ }^{7}$ Despite the numerous constraints to the expansion of AU in SubSaharan Africa, it has been demonstrated that an easy access to that technology would reduce the very high morbi-mortality rate. $^{8-13}$

The goal of our study was to assess the evolution of practice of AU in Cameroon (central Africa) over the past 3 decades.

\section{Methods}

We searched for articles in Medline (pubmed) and Google scholar. Only pertinent articles were included in our analysis. Extraction of studies and assessment of their appropriateness were done by the same investigator.

\section{Search in Google scholar}

Articles were retrieved on June 21, 2018 and languages were English and French. The period under srutiny ranged from January 1,
1990 to May 31st 2018. Only studies carried out in Cameroon with AU as primary or secondary theme were selected. Three combination of search terms were used :

a. «Ultrasonographie - anténatale - Cameroun »: 10 articles selected out of the 576 found.

b. « Echographie - Anténatale - Cameroun »: 11 articles selected out of the 479 found.

c. « Fetal - Sonography - Cameroon »: 22 articles selected out of the 354 found.

\section{Search in Medline (Pubmed)}

The characteristics of the search were as follows: date of data extraction: July 3, 2018; language of articles: English and French; period under srutiny: January 1, 1990 to May 31st, 2018; type of articles: all; Journal categories: all; Age range of subjects: all; Themes of articles: all but «Veterinary Medicine»; Text availability: abstract, full text, free full text. Only studies carried out in Cameroon with AU as primary or secondary theme were selected. Three combination of search terms were used :

i. « Fetal + echography + Cameroon $»: 5$ articles selected out of the 8 found.

ii. «Antenatal + ultrasound + Cameroon »: 4 articles selected out of the 8 found.

iii. «Antenatal + echography + Cameroon »: 2 articles selected out of the 3 found.

iv. « Obstetrical + echography + cameroon »: 7 articles selected out of the 15 found. 
After eliminating redundant articles, 48 were included in our analysis.

\section{Results}

The 48 articles over the studied period give an average of 1.81 publications /year. From 1990 to 2012 there were 0.5 publication/ year while from 2013 to 2018 there were 6 publications/year. Figure 1 shows the annual number of publications from 1990 to 2018. Table 1 summarises the distribution of articles according to the types study. Studies were carried out in Yaounde (the country's political capital) for $64.5 \%$ of articles, followed by Douala (the country's economic capital) with $22.9 \%$. The characteristics of the settings in which the studies were carried out are presented in table II. All except one study were carried out in urban settings. Table III summarizes the themes of articles and the scope and outreach of journals.

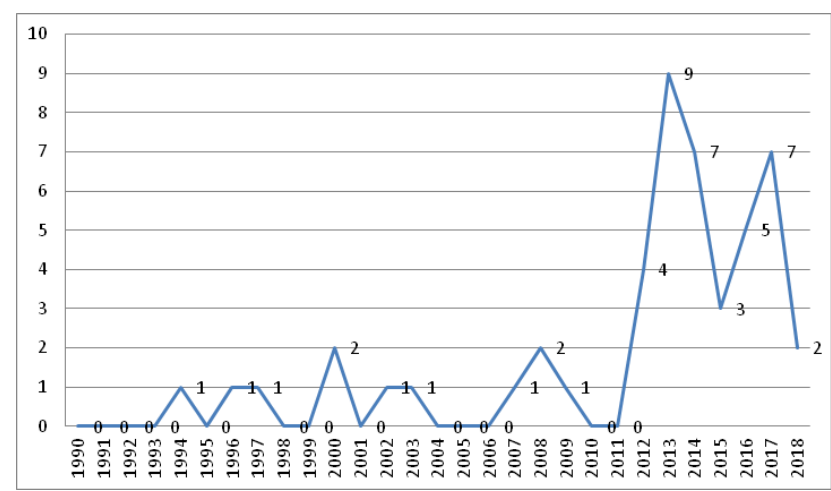

Figure I Progress in the annual number of articles on antenatal ultrasound in Cameroon from 1990 to 2018 .

the debuts of ultrasonography in the country with machines only available in the political and economic capitals (Yaounde and Douala). During the second period, a national reform of medical training was implemented: besides the unique faculty (in Yaounde) of medicine 8 faculties of medicine were opened in 6 of the 10 administrative regions of the country. ${ }^{16}$ That sharp rise in the number of lecturers of medicine (bound to carry out an publish researches) coincided with the increased availability of cheaper and lighter ultrasound machines in regional and district hospitals all over the country.

Like in other scientific domains, the political (Yaounde) and economic (Douala) capitals remain the principal sites of researches in $\mathrm{AU}$ in Cameroun. The first article in a regional setting was published in 2008 and the only one in a rural setting was published in 2015 (Table 2). One of the causes is the inbalanced geographical
Table I Distribution of articles on AU in Cameroon according to the study type (from 1990 to 2018)

\begin{tabular}{ll}
\hline Types of studies & $\mathbf{n}(\%)$ \\
\hline Case reports & \\
Case reports & $27(56.2)$ \\
Case series & $3(6.3)$ \\
Original researches & \\
Clinical & $17(35.4)$ \\
Experimental & 0 \\
Literature review & \\
Narrative & $\mathrm{I}(2.1)$ \\
Systematic (+/- meta-analysis) & 0 \\
Total & $\mathbf{4 8}(\mathbf{1 0 0 . 0 )}$ \\
\hline $\mathrm{N}=48$ &
\end{tabular}

\section{Discussion}

The annual average (1.81 article/year) of publication on AU in Cameroon is very low. This has also been noticed by several authors who stated that Africa is the continent with the lowest scientific output. ${ }^{14,15}$ Meanwhile the progress curve (Figure 1) is bi-phasic: from 1990 to 2011 there were several years without publications while from 2012 to 2018 the annual average of articles rose by 12 folds. This can be explained by two phenomenons: the increased availability of ultrasound machines and the higher number of health workers interested in scientific publications. The first period was marked by

distribution of health staff in Cameroon: $42.5 \%$ of them work in the two regions of the economic and political capitals (Douala and Yaounde); that imbalance is more important for specialists able of conducting researches and publications. ${ }^{17}$

One third of the articles (Table 3 ) were about congenital defects (CDs). Indeed, emotions ellicited by the discovery of a CD and the anecdoctic nature of its management often marked by termination of pregnancy can strongly motivate health professionals to publish the case. This was certainly more pronounced for major CDs missed during AU and discovered at birth. The same applies for gynaecoobstetrical emergencies that accounted for $20.8 \%$ of cases. Given that $\mathrm{AU}$ is the main diagnostic tool for ectopic pregancy it is logical that it was the main topic of $20.8 \%$ of articles. ${ }^{18}$

Table 2 Characteristics of the settings in which researches were conducted on antenatal ultrasound in Cameroon from 1990 to 2018

\begin{tabular}{lllll}
\hline Localities & Administrative status & Urban / Rural & n (\%) & Date of publication \\
\hline Yaounde & National political capital & Urban & 3 I (64.5) & From 1994 to 2018 \\
Douala & National economic capital & Urban & II (22.9) & From 2013 to 2017 \\
Ngaoundere & Regional capital & Urban & $2(4.2)$ & 2008 and 2013 \\
Mbengwi & Divisional capital & Urban & I (2.1) & 2018 \\
Dschang & Divisional capital & Urban & I (2.1) & 2017 \\
Foumbot & Sub-divisional capital & Urban & I (2.1) & 2017 \\
Mbingo & Village & Rural & I (2.1) & 2015 \\
\hline $\mathrm{N}=48$ & & & &
\end{tabular}


Table 3 Distribution of publications on AU according to their themes, journal scope and outreach

\begin{tabular}{|c|c|}
\hline Items & n (\%) \\
\hline \multicolumn{2}{|l|}{ Sub-fields of publications } \\
\hline Congenital defects & $16(33.3)$ \\
\hline Gynaeco-Obstetrical emergencies & $10(20.8)$ \\
\hline Ectopic pregnancy & $10(20.8)$ \\
\hline Embryo-fetal biometry & $4(8.3)$ \\
\hline Embryo-fetal and adnexal morphology & $3(6.3)$ \\
\hline Skills of practitionners in antenatal ultrasonography & $3(6.3)$ \\
\hline $\begin{array}{l}\text { Womens' expectations toward antenatal } \\
\text { ultrasonography }\end{array}$ & $2(4.2)$ \\
\hline \multicolumn{2}{|l|}{ Scope of Journals } \\
\hline General medicine & $18(37.4)$ \\
\hline Gynaecology and obstetrics & $15(3 \mid .2)$ \\
\hline Ultrasonography in Obstetrics and gynaecology & $4(8.4)$ \\
\hline Medical imaging & $3(6.3)$ \\
\hline Maternal and child health & $2(4.2)$ \\
\hline Cardiology & $2(4.2)$ \\
\hline Radiology et radiotherapy & I (2.I) \\
\hline Hand surgery and rehabilitation & I $(2.1)$ \\
\hline Neurology & I (2.I) \\
\hline Prenatal diagnosis & I (2.I) \\
\hline \multicolumn{2}{|l|}{ Outreach of the Journals } \\
\hline Global & $27(56.3)$ \\
\hline Continental (African) & $12(25.0)$ \\
\hline \multicolumn{2}{|l|}{ National } \\
\hline - Cameroon & $3(6.3)$ \\
\hline - $\quad$ France & $2(4.2)$ \\
\hline - $\quad$ Turkey & I (2.I) \\
\hline - India & I (2.I) \\
\hline - United States of America & I (2.I) \\
\hline - Jamaica & I (2.I) \\
\hline
\end{tabular}

$N=48$

Only $8.4 \%$ of articles were published in journals specialized in gyneco-obstetrical ultrasonography. This denotes that very few authors were (sub) specialized in echography and/or that manuscripts did not meet the technological and scientific requirements of those journals. Indeed the gap in specialized training of echographers in sub-Saharan Africa limits its expansion. ${ }^{14,15}$ Two other findings coroborates that fact: the predominance of clinical cases $(62.5 \%)$ and the absence of experimental research (Table 2). Journals of general medicine were predominant $(37.4 \%)$ followed by those of gyneco-obstetrics $(31.2 \%)$ and radiology $(16.8 \%)$. This is the consequence of the fact that more and more $\mathrm{AU}$ are done by obstetricians-gynaecologists and general practitionners. This can also be explained by the weak technological characteristics of the available ultrasounds machine that cannot produce high quality pictures usually required by radiology journals.

\section{Conclusion}

Scientific litterature on Antenatal Ultrasonography in Cameroon is scarce and its technological and methodological values are weak. Practionners of Antenatal Ultrasonography should get formal training.

\section{Acknowledgments}

None.

\section{Funding}

None.

\section{Conflicts of interest}

The author affirms no conflict of interest in publication of this study.

\section{References}

1. Benson B, Doubilet PM. The history of imaging in obstetrics. Radiology. 2014;273(2 Suppl):S92-S110.

2. Moore CL, Copel JA. Point-of-care ultrasonography. $N$ Engl J Med. 2011;364(8):749-757.

3. Goldberg BB. Obstetric US imaging: the past 40 years. Radiology. 2000;215(3):622-629.

4. Jahn A. Ultrasound screening in pregnancy: evidence and maternity care reality. Z Arztl Fortbild Qualitatssich. 2002;96(10):649-654.

5. Bhide A, Acharya G, Bilardo CM, et al. ISUOG Practice guidelines: use of Doppler ultrasonography in obstetrics. Ultrasound Obstet Gynecol. 2013;41:233-239.

6. Khalil A, Rodgers M, Baschat A, et al. ISUOG Practice Guidelines: role of ultrasound in twin pregnancy. Ultrasound Obstet Gynecol. 2016;47:247-263.

7. Aliyu LD, Kurjak A, Wataganara T, et al. Ultrasound in Africa: what can really be done? J Perinat Med. 2016;44(2):119-123.

8. Holmlund S, Ntaganira J, Edvardsson K, et al. Improved maternity care if midwives learn to perform ultrasound: a qualitative study of Rwandan midwives' experiences and views of obstetric ultrasound. Global Health Action. 2017;10(1):1350451.

9. Kawooya MG, Nathan RO, Swanson J, et al. Impact of introducing routine antenatal ultrasound services on reproductive health indicators in Mpigi District, Central Uganda. Ultrasound Q. 2015;31(4):285-289.

10. Swanson JO, Kawooya MG, Swanson DL, et al. The diagnostic impact of limited, screening obstetric ultrasound when performed by midwives in rural Uganda. J Perinatol. 2014;34(7):508-512.

11. Shah S, Bellows BA, Adedipe AA, et al. Perceived barriers in the used of ultrasound in developping countries. Crit Ultrasound J. 2015;7(1):28.

12. Ross AB, DeStigter KK, Rielly M, et al. A low-cost ultrasound program leads to increased antenatal clinic visits and attended deliveries at a health care clinic in rural Uganda. PLoS One. 2013;8(10):e78450.

13. Kongnyuy EJ, Van Den Broek N. The use of ultrasonography in obstetrics in developing countries. Trop Doct. 2007;37(2):70-72.

14. Carrera JM. Obstetric ultrasounds in africa: is it necessary to promote their appropriate use? Donald School Journal of Ultrasound in Obstetrics and Gynecology. 2011;5(3):289-296.

15. Stanton K, Mwanri L. Global maternal and child health outcomes: the role of obstetric ultrasound in low resource settings. World Journal of Preventive Medicine. 2013;1(3):22-29. 
16. Official Journal of the Republic of Cameroon. Stop Number 055/PM of June 05,2013 relating to the creation, organization and functioning of the national committee for the medical, pharmaceutical and odontostomatological training of Cameroon.

17. Ministry of public health - Cameroon. Cameroon analytical health profile 2016. Yaounde; 2017.
18. Dupuis O, Camagna O, Benifla JL, et al. Extra-uterine pregnancy. In: Darai E, Dommergues M, Poncelet C, editors. Encycl Méd Chir, Gynécologie/Obstétrique. Paris: Elsevier; 2001. 